\title{
HUBUNGAN INTENSITAS NYERI PUNGGUNG BAWAH UNILATERAL DENGAN DERAJAT OSTEOARTRITIS LUTUT KONTRALATERAL
}

\author{
THE CORRELATION OF UNILATERAL LOW BACK PAIN INTENSITY AND \\ THE DEGREE OF CONTRALATERAL KNEE OSTEOARTHRITIS
}

Edy Irwanto, * Dwi Pudjonarko, * Hermina Sukmaningtyas **

\section{ABSTRACT}

Introduction: Low back pain (LBP) is one of the most common and recurring forms of musculoskeletal pain. In back injuries or disc degenerative diseases that cause chronic LBP will increase the burden on the knee joint, thereby triggering or exacerbating the occurrence of osteoarthritis $(O A)$ of the knee.

Aims: To analyze the correlation of unilateral LBP intensity and the degree of contralateral knee OA.

Methods: Cross-sectional observational analytic study of LBP patients who went to the neurology polyclinic of RSUP Dr. Kariadi, Semarang, from November 2018 to March 2019. The diagnosis of knee OA was made clinically based on the Western Ontario and McMaster Universities Osteoarthritis Index (WOMAC) questionnaire and radiological with Kellgren-Lawrence scores. Fisher's exact test was used to see the correlation between variables, and the results of the bivariate analysis was continued with a logistic regression multivariate test to find out the variables that influence the degree of knee $O A$.

Results: There were 36 subjects, the majority of which were women (58.3\%) with an average age of $53.88 \pm 11.01$ years. A significant relationship was found between the unilateral LBP intensity $(p=0.004$; Odds ratio/OR=32,500) and malalignment of the knee joint ( $p=0.024$; OR=11.67) with the degree of contralateral knee OA based on the WOMAC score.

Discussion: The unilateral LBP intensity and malalignment of the knee joint can increase the risk of contralateral knee OA based on WOMAC scores of 32.5 and 11.7 times, respectively.

Keywords: Kellgren-Lawrence score, low back pain, osteoarthritis of the knee, WOMAC score

\section{ABSTRAK}

Pendahuluan: Nyeri punggung bawah (NPB) adalah salah satu bentuk nyeri muskuloskeletal yang paling umum terjadi dan dapat berulang. Pada cedera punggung atau penyakit degeneratif diskus yang menyebabkan NBP kronik akan meningkatkan beban pada sendi lutut, sehingga memicu atau memperparah terjadinya osteoartritis (OA) lutut.

Tujuan: Untuk mengetahui hubungan intensitas NPB unilateral dengan derajat OA lutut kontralateral.

Metode: Penelitian analitik observasional secara potong lintang terhadap pasien NPB yang berobat ke Poliklinik Saraf RSUP Dr. Kariadi, Semarang, pada bulan November 2018 hingga Maret 2019. Diagnosis OA lutut ditegakkan berdasarkan klinis menggunakan kuesioner Western Ontario and McMaster Universities Osteoarthritis Index (WOMAC) dan radiologis dengan skor Kellgren-Lawrence. Korelasi antar variabel menggunakan uji Fisher's exact, hasil analisis bivariat dilanjutkan dengan uji multivariat regresi logistik untuk mengetahui variabel yang berpengaruh terhadap derajat OA lutut.

Hasil: Didapatkan 36 subjek yang mayoritas perempuan (58,3\%) dengan rerata usia 53,88 $\pm 11,01$ tahun. Didapatkan hubungan yang bermakna antara intensitas NPB unilateral $(\mathrm{p}=0,004$; rasio $\mathrm{Odds} / \mathrm{RO}=32,500)$ dan malalignment sendi lutut $(\mathrm{p}=0,024 ; \mathrm{RO}=11,67)$ dengan derajat OA lutut kontralateral berdasarkan skor WOMAC.

Diskusi: Intensitas NPB unilateral dan malalignment sendi lutut dapat meningkatkan risiko terjadinya OA lutut kontralateral berdasarkan skor WOMAC masing-masing sebanyak 32,5 dan 11,7 kali.

Kata kunci: Nyeri punggung bawah, osteoartritis lutut, skor WOMAC, skor Kellgren-Lawrence

*Departemen Neurologi FK Universitas Diponegoro/RSUP Dr. Kariadi, Semarang; **Bagian Radiologi FK Universitas Diponegoro/ RSUP Dr. Kariadi, Semarang. Korespondensi: edyirwantoramlis@gmail.com.

\section{PENDAHULUAN}

Nyeri punggung bawah (NPB) adalah salah satu bentuk nyeri muskuloskeletal yang paling umum terjadi (49-90\%). Sekitar seperempatnya mendapatkan perawatan dan dapat mengalami episode berulang dalam waktu satu tahun. ${ }^{1} \mathrm{NPB}$ yang kronik merupakan kondisi kompleks dan heterogen yang dapat melibatkan mekanisme nyeri nosiseptik dan neuropatik, serta menghambat aktifitas dan memerlukan biaya perawatan yang tinggi. ${ }^{2}$ Neuropathic pain (NP) pada cedera punggung atau penyakit degeneratif diskus yang menyebabkan NPB kronik akan meningkatkan beban pada sendi lutut, 
sehingga memicu atau memperparah terjadinya osteoartritis (OA) lutut. ${ }^{3}$

NPB yang menetap dapat menyebabkan kelainan pada pola gerakan panggul, tulang belakang, dan tungkai. Selain itu, pola berjalan yang asimetris pada pasien NPB kronik dapat terjadi oleh adanya rasa nyeri, parestesi, serta menurunnya kecepatan berjalan dan perilaku untuk menghindari nyeri dengan membatasi gerakan tulang belakang. ${ }^{4}$

Rasa nyeri atau kecacatan pada salah satu tungkai dapat membebani tungkai yang lain dan menimbulkan gejala pada tungkai tersebut. Sering dikatakan bahwa cedera yang menyebabkan kecacatan pada salah satu tungkai memicu atau memperparah terjadinya disabilitas pada tungkai yang normal atau yang berlawanan. Keadaan ini sangat membebani tungkai yang normal karena harus menahan berat yang berlebih, menyebabkan atau mempercepat terjadinya artritis pada salah satu sendi (biasanya lutut). ${ }^{5}$

\section{TUJUAN}

Untuk menganalisis hubungan NPB unilateral dengan derajat OA lutut kontralateral baik secara klinis maupun radiologis.

\section{METODE}

Penelitian analitik observasional secara potong lintang terhadap pasien NPB di Poliklinik Saraf dan Bagian Radiologi RSUP Dr. Kariadi Semarang pada bulan November 2018 hingga Maret 2019. Diagnosis OA lutut ditegakkan berdasarkan klinis menggunakan kuesioner Western Ontario and McMaster Universities Osteoarthritis Index (WOMAC) dan radiologis dengan skor KellgrenLawrence. Subjek ditanyakan aktivitas fisik yang banyak menggunakan lutut atau riwayat trauma yang dapat menyebabkan keadaan OA genu. Kriteria aktivitas yang banyak menggunakan lutut merupakan aktivitas yang membutuhkan kegiatan berulang dengan posisi tertentu, seperti posisi berlutut, posisi berjongkok, mengangkat beban berat dan menaiki tangga. ${ }^{6}$ Penilaian klinis dengan WOMAC mengukur intensitas nyeri lutut, kekakuan dan gangguan aktivitas yang terkait dengan OA lutut, yaitu ringan $<60$, sedang (60-80), dan berat $(>80))^{7-8}$ Kellgren-
Lawrence menilai derajat OA lutut secara objektif dengan menggunakan foto rontgen genu yang terdiri atas 4 derajat, yaitu: 1) kemungkinan adanya osteofit; 2) terdapat penyempitan celah sendi dan sedikit osteofit; 3) penyempitan celah sendi dan osteofit moderat; 4) osteofit besar dengan sklerosis dan deformitas tulang. ${ }^{9}$

Pada subjek yang normal dan KellgrenLawrence derajat 1 dimasukkan ke dalam kriteria ringan, sedangkan subjek derajat 2,3, dan 4 dimasukkan dalam kriteria sedang-berat. Skoring tersebut digunakan untuk mengonfirmasi hasil kuesioner WOMAC bahwa gejala klinis didukung oleh kelainan secara radiologis. Pemeriksaan foto Rontgen genu sekaligus menilai adanya malaligment sendi lutut menggunakan alat goniometer.

Subjek dilakukan anamnesis dan pemeriksaan fisik untuk menegakkan diagnosis NPB. Intensitas nyeri dinilai menggunakan visual analogue scale (VAS) dengan kriteria ringan (skor 1-3), sedang (skor 4-6), dan berat (skor 7-10).

Korelasi antar variabel diuji menggunakan uji Fisher's exact, sedangkan hasil analisis bivariat dianalisis lebih lanjut dengan uji multivariat regresi logistik

\section{HASIL}

Didapatkan 36 subjek yang mayoritas $(58,3 \%)$ perempuan dengan rerata usia $53,88 \pm 11,01$ tahun

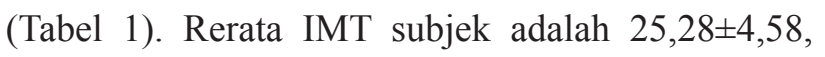
sebanyak $44,4 \%$ yang mengalami obesitas. Hanya sekitar 30\% subjek yang banyak menggunakan lutut untuk aktifitas fisiknya. Riwayat trauma lutut sebanyak 13,9\% subjek dan 38,9\% yang mengalami malalignment sendi lutut.

Sebagian besar subjek (66,7\%) mempunyai riwayat mengangkat beban dengan berat $>10 \mathrm{~kg}$, mengalami intensitas NPB ringan-sedang (75\%), derajat $\mathrm{OA}$ rendah $(83,3 \%)$ berdasarkan skor WOMAC, dan derajat OA normal-derajat 1 (rendah) berdasarkan skor Kellgren-Lawrence.

Tabel 2 menunjukkan hubungan yang bermakna pada intensitas NPB unilateral $(\mathrm{p}=0,002$; $\mathrm{RO}=32,500)$ dan malaligment sendi lutut $(\mathrm{p}=0,024$; 
Tabel 1. Karekteristik Subjek Penelitian $(n=36)$

\begin{tabular}{lcc}
\hline \multicolumn{1}{c}{ Karakteristik } & $\begin{array}{c}\text { Frekuensi } \\
(\%)\end{array}$ & Rerata \pm SD \\
\hline Usia & \multicolumn{2}{c}{$53,88 \pm 11,01$} \\
- $\geq 40$ th & $5(86,1)$ \\
- $<40$ th & $5(13,9)$ \\
Jenis Kelamin & \\
- Laki-laki & $15(41,7)$ \\
- Perempuan & $21(58,3)$ \\
Aktifitas Fisik & \\
Menggunakan Lutut & \\
- Banyak menggunakan lutut & $11(30,6)$ \\
- Tidak banyak menggunakan & $25(69,4)$ \\
$\quad$ lutut &
\end{tabular}

\section{Status Nutrisi}

$25,28 \pm 4,58$

- Tidak obesitas

- Obesitas

Riwayat Mengangkat Beban

- Beban $\geq 10 \mathrm{~kg}$

- Beban $<10 \mathrm{~kg}$

Riwayat Trauma Lutut

- Ya

- Tidak

$31(86,1)$

\section{Status Hormonal}

- Perempuan menopause

$17(80,9)$

- Perempuan tidak menopause

\section{Malalignment Sendi Lutut}

- Normal

- Malalignment

Intensitas NPB Unilateral

- Berat

- Sedang-ringan

$27(75,0)$

Derajat OA Lutut dengan Skor WOMAC

- Risiko rendah

- Risiko sedang-berat

$6(16,7)$

Derajat OA Lutut dengan Skor Kellgren-Lawrence

- Normal-derajat 1 (rendah)

- Derajat 2, 3, 4 (sedang- $11(30,5)$ berat)

NPB: nyeri punggung bawah; OA: osteoartriris; SD: standar deviasi; WOMAC: Western Ontario and McMaster Universities Osteoarthritis Index.
$\mathrm{RO}=11,667)$ dengan kejadian OA lutut kontralateral menggunakan skor WOMAC, yaitu semakin berat NPB unilateral dan malaligmnent sendi lutut pada subjek maka semakin berat pula derajat OA lutut yang dialami. Sementara tidak didapatkan hubungan antara faktor-faktor tersebut dengan derajat OA lutut berdasarkan skor Kellgren-Lawrence (Tabel 3).

Dilakukan analisis multivariat dengan uji regresi logistik antara faktor-faktor yang menunjukkan hubungan terhadap derajat OA lutut kontralateral (Tabel 4 dan 5). Hasil analisis multivariat menunjukkan variabel yang paling berpengaruh terhadap peningkatan derajat OA lutut berdasarkan skor WOMAC (Tabel 4) adalah intensitas NPB unilateral $(p=0,004 ; R O=32,500)$. Semakin berat intensitas NPB unilateral semakin berat pula derajat OA lutut kontralateral secara klinis. Namun tidak didapatkan hubungan yang sama terhadap derajat OA berdasarkan skor Kellgren-Lawrence.

\section{PEMBAHASAN}

Penelitian ini mendapatkan 36 subjek dengan NPB yang mayoritas perempuan $(58,3 \%)$ dengan rerata usia 53,88 $\pm 11,01$ tahun. Penelitian Meucci dkk. menyebutkan kasus NPB paling banyak pada jenis kelamin perempuan dan usia terbanyak di atas 60 tahun. ${ }^{10}$ Hanya sekitar 30\% subjek yang banyak menggunakan lutut untuk aktifitas fisiknya. Sebagian besar subjek $(66,7 \%)$ mempunyai riwayat mengangkat beban dengan berat $>10 \mathrm{~kg}$ yang berisiko menyebabkan mikrotrauma berulang akibat aktifitas pada lutut yang mengakibatkan terjadinya OA lutut. Faktor risiko lainnya yang dapat menyebabkan terjadinya OA lutut terdiri dari riwayat trauma lutut sebanyak $13,9 \%$ subjek dan 38,9\% subjek mengalami malalignment sendi lutut.

Uji analisis pada penelitian ini menunjukkan hubungan yang bermakna antara intensitas NPB unilateral dengan derajat $\mathrm{OA}$ lutut kontralateral berdasarkan skor WOMAC yang berarti semakin berat NPB unilateral yang dialami maka subjek akan lebih menumpu pada lutut kontralateral yang akan menyebabkan beban berlebih pada lutut tersebut, sehingga dapat menyebabkan terjadinya OA lutut. Hal ini sesuai dengan penelitian Iijima yang 
Tabel 2. Hubungan Faktor Perancu dengan Derajat Osteoartritis Lutut Berdasarkan skor WOMAC (n=36)

\begin{tabular}{|c|c|c|c|c|c|}
\hline \multirow[b]{2}{*}{ Variabel } & \multicolumn{2}{|c|}{ Skor WOMAC } & \multirow[b]{2}{*}{$\mathbf{p}$} & \multirow[b]{2}{*}{ RO } & \multirow[b]{2}{*}{ IK 95\% } \\
\hline & $\begin{array}{c}\text { Sedang-Tinggi } \\
\text { n }(\%)\end{array}$ & $\begin{array}{l}\text { Rendah } \\
\text { n (\%) }\end{array}$ & & & \\
\hline \multicolumn{6}{|l|}{ Jenis Kelamin } \\
\hline - Laki-laki & $3(20)$ & $12(80)$ & $0,677^{£}$ & 1,500 & $0,258-8,711$ \\
\hline - Perempuan & $3(14,3)$ & $18(85,7)$ & & & \\
\hline \multicolumn{6}{|l|}{ Usia } \\
\hline - $\geq 40$ th & $6(19,4)$ & $25(80,6)$ & $0,564^{£}$ & - & - \\
\hline - $<40$ th & $0(0)$ & $5(100)$ & & & \\
\hline \multicolumn{6}{|c|}{$\begin{array}{l}\text { Aktifitas Fisik Menggunakan } \\
\text { Lutut }\end{array}$} \\
\hline - Banyak & $4(36,4)$ & $7(63,6)$ & $0,057^{\mathfrak{1}}$ & 6,571 & $0,986-43,784$ \\
\hline - Tidak banyak & $2(8)$ & $23(92)$ & & & \\
\hline \multicolumn{6}{|l|}{ IMT } \\
\hline - Obesitas & $4(25)$ & $12(75)$ & $0,374^{£}$ & 3,000 & $0,473-19,039$ \\
\hline - Tidak obesitas & $2(10)$ & $18(90)$ & & & \\
\hline \multicolumn{6}{|c|}{ Riwayat Angkat Beban } \\
\hline - $\quad \geq 10 \mathrm{~kg}$ & $5(20,8)$ & $19(79,2)$ & $0,640^{£}$ & 2,895 & $0,299-28,070$ \\
\hline - $\quad<10 \mathrm{~kg}$ & $1(8,3)$ & $11(91,7)$ & & & \\
\hline \multicolumn{6}{|c|}{ Riwayat Trauma Lutut } \\
\hline - $\mathrm{Ya}$ & $2(40)$ & $3(60)$ & $0,186^{£}$ & 4,500 & $0,565-35,825$ \\
\hline - Tidak & $4(12,9)$ & $27(87,1)$ & & & \\
\hline \multicolumn{6}{|l|}{ Menopause } \\
\hline - $\mathrm{Ya}$ & $2(12,5)$ & $14(87,5)$ & 1,000 & - & - \\
\hline - Tidak & $0(0)$ & $4(100)$ & & & \\
\hline \multicolumn{6}{|c|}{ Malalignment Sendi Lutut } \\
\hline - $\mathrm{Ya}$ & $5(35,7)$ & $9(64,3)$ & $0,024^{£ *}$ & 11,667 & $1,188-114,59$ \\
\hline - Tidak & $1(4,5)$ & $21(95,5)$ & & & \\
\hline \multicolumn{6}{|c|}{ Intensitas NPB Unilateral } \\
\hline - Berat & $5(55,6)$ & $4(44,4)$ & $0,002^{£ *}$ & 32,500 & $2,974-355,12$ \\
\hline - Sedang-ringan & $1(3,7)$ & $26(96,3)$ & & & \\
\hline
\end{tabular}

*Signifikan $(\mathrm{p}<0,05)$; ${ }^{\mathfrak{f}}$ Fisher's exact; IMT: indeks massa tubuh; WOMAC: Western Ontario and McMaster Universities Osteoarthritis Index; RO: rasio Odds; IK: interval kepercayaan; NPB: nyeri punggung bawah.

mengungkapkan bahwa hubungan antara intensitas nyeri dan tingkat kecacatan lutut lebih tinggi pada individu dengan NPB dibandingkan tanpa NPB. ${ }^{11}$

Mekanisme yang mendasari keterkaitan NPB dengan nyeri lutut masih diperdebatkan, namun terdapat dua mekanisme yang diakui. Pertama NPB secara langsung dapat menyebabkan penambahan muatan sendi lutut melalui rantai kinetik, yang disebut sindroma lutut-tulang belakang yang meningkatkan nyeri lutut. Kedua, NPB mungkin menjadi penanda secara intrinsik tingkat nyeri lutut yang lebih tinggi dan kondisinyeri sendi menyeluruh. Lee menyebutkan bahwa NPB dan derajat OA lutut secara radiografis (skor Kellgren-Lawrence) berkaitan dengan derajat nyeri lutut pada seluruh kelompok penelitian. ${ }^{12}$

Pada uji korelasi antara intensitas NPB unilateral dengan derajat $\mathrm{OA}$ lutut kontralateral secara radiografis dengan skor Kellgren-Lawrence pada penelitian ini didapatkan hasil yang tidak bermakna. Adanya perbedaan hasil antara skor 
Tabel 3. Hubungan Faktor Perancu dengan Derajat Osteoartritis lutut Berdasarkan Skor Kellgren-Lawrence

\begin{tabular}{|c|c|c|c|c|c|}
\hline \multirow[b]{2}{*}{ Variabel } & \multicolumn{2}{|c|}{ Kellgren-Lawrence } & \multirow[b]{2}{*}{$\mathbf{p}$} & \multirow[b]{2}{*}{ RO } & \multirow[b]{2}{*}{ IK 95\% } \\
\hline & $\begin{array}{c}\text { Sedang-Berat } \\
\text { n (\%) }\end{array}$ & $\begin{array}{c}\text { Ringan } \\
\text { n (\%) }\end{array}$ & & & \\
\hline \multicolumn{6}{|l|}{ Jenis Kelamin } \\
\hline - Laki-laki & $6(40)$ & $9(60)$ & $0,465^{\mathfrak{1}}$ & 2,133 & $0,505-9,010$ \\
\hline - Perempuan & $5(23,8)$ & $16(76,2)$ & & & \\
\hline \multicolumn{6}{|l|}{ Usia } \\
\hline - $\geq 40$ th & $11(35,5)$ & $20(64,5)$ & $0,295^{\mathfrak{1}}$ & - & - \\
\hline - $<40$ th & $0(0)$ & $5(100)$ & & & \\
\hline \multicolumn{6}{|c|}{ Aktifitas Fisik Menggunakan Lutut } \\
\hline - Banyak & $5(45,5)$ & $6(54,5)$ & $0,252^{\mathrm{f}}$ & 2,639 & $0,589-11,830$ \\
\hline - Tidak banyak & $6(24)$ & $19(76)$ & & & \\
\hline \multicolumn{6}{|l|}{ IMT } \\
\hline - Obesitas & $7(43,8)$ & $9(56,3)$ & $0,159^{\mathfrak{t}}$ & 3,111 & $0,712-13,601$ \\
\hline - Tidak obesitas & $4(20)$ & $16(80)$ & & & \\
\hline \multicolumn{6}{|l|}{ Riwayat Angkat Beban } \\
\hline - $\geq 10 \mathrm{~kg}$ & $7(29,2)$ & $17(70,8)$ & $1,000^{£}$ & 0,824 & $0,186-3,648$ \\
\hline - $\quad<10 \mathrm{~kg}$ & $4(33,3)$ & $8(66,7)$ & & & \\
\hline \multicolumn{6}{|l|}{ Riwayat Trauma Lutut } \\
\hline - $\mathrm{Ya}$ & $3(60)$ & $2(40)$ & $0,154^{£}$ & 4,313 & $0,606-30,669$ \\
\hline - Tidak & $8(25,8)$ & $23(74,2)$ & & & \\
\hline \multicolumn{6}{|l|}{ Menopause } \\
\hline - $\mathrm{Ya}$ & $5(31,3)$ & $11(68,8)$ & 0,530 & - & - \\
\hline - Tidak & $0(0)$ & $4(100)$ & & & \\
\hline \multicolumn{6}{|c|}{ Malalignment Sendi Lutut } \\
\hline - $\mathrm{Ya}$ & $5(35,7)$ & $9(64,3)$ & $0,716^{\mathfrak{f}}$ & 1,481 & $0,351-6,257$ \\
\hline - Tidak & $6(27,3)$ & $16(72,7)$ & & & \\
\hline \multicolumn{6}{|c|}{ Intensitas NPB Unilateral } \\
\hline - Berat & $4(44,4)$ & $5(55,6)$ & $0,409^{\mathfrak{1}}$ & 2,286 & $0,475-11,003$ \\
\hline - Sedang-ringan & $7(25,9)$ & $20(74,1)$ & & & \\
\hline
\end{tabular}

WOMAC dengan skor Kellgren-Lawrence ini bisa disebabkan oleh karakteristik OA yang unik menurut Yucesoy dkk. Beberapa individu dengan gejala klinis OA bisa tanpa menunjukkan gambaran OA secara radiografis, begitu juga sebaliknya individu yang telah dikonfirmasi secara radiografis menderita OA bisa tanpa adanya gejala klinis. ${ }^{13}$

Hasil studi kami menunjukkan antara usia dengan derajat $\mathrm{OA}$ lutut kontralateral dengan skor WOMAC dan skor Kellgren-Lawrence pada penelitian ini didapatkan hasil yang tidak bermakna.
Hal ini tidak sesuai dengan penelitian Lee yang menyebutkan usia memiliki hubungan yang bermakna dengan tingkat nyeri lutut, semakin tinggi usia semakin bertambah derajat nyeri lutut pada seluruh kelompok penelitiannya. ${ }^{12}$ Hal ini mungkin disebabkan oleh usia subjek yang bervariasi. Ada dua subjek yang berusia di bawah 30 tahun. Karena pada penelitian ini tidak menilai OA lutut akibat proses degeneratif melainkan OA lutut akibat faktor mekanik sehingga faktor usia tidak bermakna.

Pada penelitian ini, hubungan IMT dengan derajat OA lutut kontralateral menunjukkan korelasi 
Tabel 4. Hasil Analisis Regresi Logistik Faktor yang Berpengaruh terhadap Derajat Osteoartritis Lutut Berdasarkan Skor WOMAC

\begin{tabular}{lccccc}
\hline \multicolumn{1}{c}{ Variabel WOMAC } & B & SE & p & RO & IK 95\% \\
\hline $\begin{array}{l}\text { Intensitas NPB Unilateral } \\
\text { - Berat }\end{array}$ & 3,481 & 1,220 & $0,004^{*}$ & 32,500 & $2,974-355,116$ \\
- Sedang-ringan & & & & & \\
$\begin{array}{l}\text { Riwayat Trauma Lutut } \\
\text { - Ya }\end{array}$ & 1,691 & 1,862 & 0,364 & 5,426 & $0,141-208,847$ \\
- Tidak & & & & & \\
& $\begin{array}{l}\text { Malalignment Sendi Lutut } \\
\text { - Ya }\end{array}$ \\
$\begin{array}{l}\text { - Normal } \\
\text { *Signifikan (p<0,05); WOMAC: Western Ontario and McMaster Universities Osteoarthritis Index; RO: rasio Odds; IK: interval } \\
\text { kepercayaan; NPB: nyeri punggung bawah. }\end{array}$
\end{tabular}

Tabel 5. Hubungan Faktor Perancu dengan Derajat Osteoartritis Lutut Berdasarkan Skor Kellgren-Lawrence (n=36)

\begin{tabular}{lccccc}
\hline Kellgren-Lawrence & B & SE & p & RO & IK 95\% \\
\hline $\begin{array}{l}\text { Indeks Massa Tubuh } \\
\text { - Obesitas } \\
\text { - Tidak obesitas }\end{array}$ & 1,135 & 0,753 & 0,132 & 3,111 & $0,712-13,601$ \\
$\begin{array}{l}\text { Riwayat Trauma Lutut } \\
\text { - Ya }\end{array}$ & & & & & \\
- Tidak & 1,137 & 1,046 & 0,277 & 3,117 & $0,401-11,734$ \\
*Signifikan (p<0,05); ${ }^{*}$ Fisher's exact; IMT: indeks massa tubuh; RO: rasio Odds; IK: interval kepercayaan; NPB: nyeri punggung bawah.
\end{tabular}

yang tidak bermakna, baik menggunakan skor WOMAC ataupun skor Kellgren-Lawrence. Hal ini bertentangan dengan penelitian Lee yang menyebutkan bahwa IMT merupakan faktor signifikan yang terkait dengan tingkat nyeri lutut. ${ }^{12}$ Penelitian meta-analisis oleh Zeng dengan rancang penelitian kohort mendapatkan hasil yang bermakna antara IMT dengan derajat OA lutut, bahwa semakin tinggi IMT semakin berat derajat OA lutut subjek. Kegemukan dan obesitas secara bermakna berkaitan dengan risiko OA lutut. ${ }^{14}$ Pada penelitian ini tidak bermakna dimungkinkan karena rerata IMT subjek yang tidak obesitas $(25,28 \pm 4,58)$.

Pada penelitian ini, hubungan jenis kelamin dengan derajat OA lutut kontralateral menunjukkan korelasi yang tidak bermakna, baik menggunakan skor WOMAC ataupun skor Kellgren-Lawrence. Hal ini bertentangan dengan penelitian Glass yang menyebutkan bahwa perempuan memiliki risiko yang lebih tinggi mengalami OA lutut pada usia lebih $>50$ tahun. Pada penelitian ini subjek perempuan sebagian besar hanya menderita OA lutut derajat ringan sehingga tidak menunjukan hubungan yang bermakna.

Dikatakan perempuan mengalami OA lutut dengan stadium lebih lanjut dan kecacatan yang lebih tinggi dibandingkan laki-laki. Hal ini dimungkinkan oleh adanya perbedaan hormon reproduksi, komposisi tubuh, karakteristik psikososial, struktur lutut, proses pengaturan saraf serta adanya perbedaan struktur tubuh laki-laki dan perempuan yaitu ketebalan kartilago, volume dan permukaan sendi. ${ }^{15-16}$ Culvenor dkk menyebutkan bahwa temuan pada pemeriksaan MRI lutut seperti robekan meniskus, cacat tulang rawan, lesi sumsum tulang, osteofit dan lainnya yang merupakan gambaran dari OA lutut sering lebih banyak ditemukan pada perempuan. ${ }^{17}$

Pada penelitian ini, hubungan riwayat aktifitas fisik menggunakan lutut dengan derajat OA lutut kontralateral menunjukkan korelasi yang tidak bermakna pada skor WOMAC dan skor KellgrenLawrence. Penelitian Verbeek dkk, didapatkan hasil aktifitas fisik menggunakan lutut yang membutuhkan 
tekukan lutut dan berjongkok atau membawa beban berat dan memanjat memiliki derajat OA lutut yang lebih tinggi daripada pekerja yang tidak memerlukan kegiatan ini. ${ }^{18}$ Hasil tidak bermakna pada penelitian ini mungkin disebabkan penilaian riwayat aktifitas fisik menggunakan lutut hanya menilai frekuensinya saja, kurang spesifik menunjukkan bentuk aktifitas yang dikerjakan seperti riwayat menekuk lutut, mengangkat lutut, mengangkat beban berat yang dapat menyebabkan terjadinya OA lutut.

Pada penelitian ini, hubungan riwayat angkat beban dengan derajat OA lutut kontralateral menunjukkan korelasi yang tidak bermakna, baik menggunakan skor WOMAC ataupun skor KellgrenLawrence. Hal ini bertentangan dengan penelitian oleh Verbeek dkk, mengangkat beban berat berhubungan dengan kejadian OA lutut. ${ }^{18}$ Penelitian Sandmark dkk, menyebutkan adanya hubungan yang bermakna antara riwayat mengangkat beban berat dan derajat OA lutut, namun pada penelitian tersebut dilakukan penggalian data subjek secara lebih detail seperti menanyakan durasi pekerjaan, jumlah anak tangga yang dilalui tiap harinya, beban dan frekuensi mengangkat beban, dan jumlah mengangkat lutut per harinya. ${ }^{19}$ Perbedaan hasil pada penelitian ini dapat disebabkan oleh adanya kesalahan atau keterbatasan daya ingat subjek dalam menentukan jumlah beban yang pernah diangkat.

Cedera lutut merupakan faktor risiko penting untuk OA dan lutut dan dapat menyebabkan onset awal OA lutut. Pada penelitian ini, uji korelasi riwayat trauma lutut dengan derajat OA lutut kontralateral menunjukkan korelasi yang tidak bermakna pada skor Kellgren-Lawrence dan skor WOMAC. Hal ini tidak sesuai dengan penelitian Driban dkk bahwa cedera lutut mungkin menjadi faktor risiko penting untuk percepatan terjadinya OA lutut, yang memicu kegagalan sendi pada waktu kurang dari satu tahun. Sebanyak 13 dari 17 subjek dengan percepatan terjadinya OA lutut mengalami cedera lutut pada satu tahun sebelum terjadi OA tahap lanjut (skor KellgrenLawrence). ${ }^{20}$

Menurut penelitian Hussain dkk hormon seks endogen, faktor reproduksi, dan suplementasi hormon berperan dalam patogenesis OA lutut. Peranan estrogen yang lebih besar dapat melawan perubahan osteoartritik dengan mempertahankan tulang rawan artikular dan tulang subkondral..$^{21}$ Perempuan usia tua berisiko tinggi terjadi OA di semua sendi, risiko ini muncul saat dekade keenam. Kehilangan hormon saat menopause dapat berkontribusi terjadinya OA. ${ }^{22}$ Pada penelitian ini, uji korelasi status hormonal dengan derajat OA lutut kontralateral menunjukkan korelasi yang tidak bermakna, baik menggunakan skor WOMAC ataupun skor Kellgren-Lawrence. Hal yang menyebabkan kondisi tersebut bahwa pada penelitian ini tidak diperhatikan apakah subjek sudah menjalani terapi suplementasi hormon eksogen atau tidak, sehingga bisa menyebabkan bias data.

Static varus alignment pada lutut dikaitkan dengan peningkatan risiko OA lutut bagian medial, dan valgus alignment meningkatkan risiko OA lutut bagian lateral. Kelemahan sendi lutut terutama pada keadaan varus-valgus juga dapat mempercepat terjadinya OA lutut. Perubahan bentuk tulang seperti dislokasi kongenital pada pinggul, impaksi femoroasetabular dan displasia epifisis juga dapat mempercepat terjadinya OA lutut. ${ }^{23}$ Pada penelitian ini, uji korelasi antara malalignment sendi lutut dengan derajat OA lutut kontralateral menunjukkan korelasi yang bermakna pada skor WOMAC dan tidak bermakna pada skor Kellgren-Lawrence. Hal ini bisa disebabkan proses malalignment sendi lutut yang masih awal, sehingga hanya menyebabkan keluhan nyeri pada subjek, namun belum terjadi perubahan yang signifikan pada struktur anatomi sendi lutut.

Pada analisis multivariat didapatkan variabel intensitas NPB unilateral berhubungan secara bermakna dengan derajat OA lutut kontralateral dengan menggunakan penilaian skor WOMAC baik sendiri maupun bersama variabel yang lain. Intensitas NPB unilateral memiliki risiko 32,5 kali meningkatkan terjadinya OA lutut kontralateral $(\mathrm{RO}=32,500 ; \mathrm{p}=0,004)$, sedangkan saat menggunakan skor Kellgren-Lawrence tidak terdapat variabel yang baik sendiri maupun bersama variabel lain berkaitan secara bermakna dengan derajat OA lutut kontralateral. 
Penelitian ini mempunyai keterbatasan yaitu hanya memperhitungkan onset NPB unilateral $\geq 3$ bulan dantidakmemperhitungkan lama onsetsetelahituyang dapat memengaruhi derajat OA lutut kontralateral. Penelitian ini juga tidak memperhitungkan riwayat fisioterapi dan riwayat minum obat-obatan anti nyeri yang dapat memengaruhi intensitas NPB, tidak melakukan pemeriksaan Rontgen genu pada kedua lutut untuk menyingkirkan OA lutut akibat proses degeneratif, tidak memperhitungkan adanya riwayat osteoporosis dan tidak memperhitungkan adanya suplementasi estrogen eksogen yang dilakukan oleh subjek. Selain itu, pada penelitian ini didapatkan indeks kepercayaan dengan rentang yang cukup lebar sehingga memiliki tingkat presisi yang cukup rendah dimungkinkan karena jumlah sampel yang sedikit.

\section{KESIMPULAN}

Semakin berat intensitas NPB unilateral semakin berat pula derajat OA lutut kontralateral. Berdasarkan skor WOMAC, intensitas NPB unilateral meningkatkan risiko terjadinya OA lutut kontralateral sebanyak 32,5 kali dan malalignment sendi lutut juga dapat meningkatkan kejadian OA lutut kontralateral, namun bukan merupakan faktor yang dominan.

\section{DAFTAR PUSTAKA}

1. Edwards J, Hayden J, Asbridge M, Gregoire B, Magee K. Prevalence of low back pain in emergency settings: a systematic review and meta-analysis. BMC Musculoskelet Disord. 2017;18(1):143.

2. Baron R, Binder A, Attal N, Casale R, Dickenson AH, Treede RD. Neuropathic low back pain in clinical practice. Eur J Pain. 2016;20:861-73.

3. Harrington IJ. Limping and back pain. The Workplace Safety and Insurance Appeals Tribunal. 2013:2013:118.

4. Seo KE, Park TJ. Effects of gyrokinesis exercise on the gait pattern of female patients with chronic low back pain. J Phys Ther Sci. 2016;28(2):511-4.

5. Harrington IJ. Symptoms in the opposite or uninjured leg. The Workplace Safety and Insurance Appeals Tribunal. 2005;2005:1-21.

6. Dulay GS, Cooper C, Dennison EM. Knee pain, knee injury, knee osteoarthritis \& work. Best Pract Res Clin Rheumatol. 2015;29(3):454-61.

7. George H. Patient reported measures of physical activity in knee osteoarthritis. Hhs Public Access. 2016;1848(10):3047-54.
8. Sathiyanarayanan S, Shankar S, Padmini SK. Usefulness of WOMAC index as a screening tool for knee osteoarthritis among patients attending a rural health care center in Tamil Nadu. Int J Community Med Public Heal. 2017;4(11):4290.

9. Kohn MD, Sassoon AA, Fernando ND. Classifications in brief: Kellgren-Lawrence classification of osteoarthritis. Clin Orthop Relat Res. 2016;474(8):1886-93.

10. Meucci RD, Fassa AG, Faria NMX. Prevalence of chronic low back pain: systematic review. Rev Saude Publica. 2015;49:1-10.

11. Iijima H, Suzuki $Y$, Aoyama $T$, Takahashi M. Interaction between low back pain and knee pain contributes to disability level in individuals with knee osteoarthritis: a cross-sectional study. Osteoarthr Cartil. 2018;26(10):1319-25.

12. Lee KM, Kang SB, Chung CY, Park MS, Kang DW, Chang CB. Factors associated with knee pain in 5148 women aged 50 years and older: A population-based study. PLoS One. 2018;13(3):1-9.

13. Yucesoy B, Charles LE, Baker B, Burchfiel $\mathrm{CM}$. Occupational and genetic risk factors for osteoarthritis: a review. Work. 2015;50(2):261-73.

14. Zheng H, Chen C. Body mass index and risk of knee osteoarthritis: Systematic review and meta-analysis of prospective studies. BMJ Open. 2015;5(12).

15. Glass N, Segal NA, Sluka KA, Torner JC, Nevitt MC, Felson DT, dkk. Examining sex differences in knee pain: the multicenter osteoarthritis study. Osteoarthr Cartil. 2014;22(8):1100-6.

16. Kumar D, Souza RB, Subburaj K, MacLeod TD, Singh J, Calixto NE, dkk. Are there sex differences in knee cartilage composition and walking mechanics in healthy and osteoarthritis populations? Clin Orthop Relat Res. 2015;473(8):2548-58.

17. Culvenor AG, Øiestad BE, Hart HF, Stefanik JJ, Guermazi A, Crossley KM. Prevalence of knee osteoarthritis features on magnetic resonance imaging in asymptomatic uninjured adults: a systematic review and meta-analysis. Br J Sports Med. 2019;53(20):1268-78.

18. Verbeek J, Mischke C, Robinson R, Ijaz S, Kuijer P, Kievit A, dkk. Occupational exposure to knee loading and the risk of osteoarthritis of the knee: a systematic review and a dose-response meta-analysis. Saf Health Work. 2017;8(2):130-42.

19. Sandmark H, Hogstedt C, Vingård E. Primary osteoarthrosis of the knee in men and women as a result of lifelong physical load from work. Scand J Work Environ Heal. 2000;26(1):20-5.

20. Driban JB, Eaton CB, Lo GH, Ward RJ, Lu B, McAlindon TE. Association of knee injuries with 
accelerated knee osteoarthritis progression: data from the osteoarthritis initiative. Arthritis Care Res. 2014;66(11):1673-9.

21. Hussain SM, Cicuttini FM, Alyousef B, Wang Y. Female hormonal factors and osteoarthritis of the knee, hip and hand: a narrative review. Climacteric. 2018;21(2):132-9.
22. Felson DT. Osteoarthritis. Dalam: Kasper DL, Hauser SL, Jameson JL, Fauci AS, Longo DL, Loscalzo J, editor. Harrison princiles of internal medicine. Edisi Ke-19. McGraw-Hill Education; 2015. h. 2226-34.

23. Conaghan PG, Nelson AE. Fast facts: osteoarthritis. Edisi Ke-2. Health Press Limited. 2009. h. 37-47. 